\title{
The Determinants and Consequences of District Partisan Change and Intactness in the Congressional Redistricting Process: An Integrative Model
}

\author{
Richard Born \\ Vassar College
}

\begin{abstract}
In this study of redistricting from 1992 to 2012, we develop an integrative path analysis model that links together the two parts of the congressional redistricting process: the impact of political and environmental antecedent variables on district partisan change and constituency intactness, and the subsequent impact that partisan chance and intactness have on incumbent reelection margin. Environmental factors, most notably the extent of a district's overor under-population prior to redistricting, are found to ultimately make more difference on safety than does party control of the redistricting plan. Furthermore, the pathways extending through partisan change are more important for members' reelection margin than are the pathways extending through intactness. Since members typically end up with a sizable share of new constituents, however, whereas a fairly even balance exists between districts left with pro-incumbent or anti-incumbent partisan change, the average member actually has somewhat more to fear from the former product of the redistricting process.
\end{abstract}

Research on redistricting has amply demonstrated that those in charge of redrawing congressional district lines have two basic mechanisms available to achieve partisan objectives. The more obvious, of course, is the manipulation of district partisanship to make a seat more or less safe for a party. More recent research shows, however, that the very act of adding new constituents to a district, independent of their partisanship, may itself reduce an incumbent's reelection margin. The relevant causal factor involves diminution in the magnitude of the incumbent's "personal vote"; i.e., that part of election margin arising from elements unrelated to partisan identification. The personal vote is rooted in the member's personal characteristics, attentiveness to constituency service functions like casework and pork-barreling, and name recognition. Absent such familiarity with the incumbent, therefore, newly transplanted constituents may see both candidates essentially as the equivalent of challengers facing off in an open seat contest (Ansolabehere, Snyder, Jr., and Stewart, III, 2000, 23-27; Hood and McKee, 2010, 345-38; McKee, 2008b, 963-64; Rush, 2000, 55; Yoshinaka and Murphy, 2011, 438). ${ }^{1}$

Redistricted members, however, may be able to ward off some of the potential damage linked to impaired district intactness by adjusting their roll call behavior to better fit the median ideological position of their new constituency and opening up campaign offices in the appended areas well in advance of election day (Boatright, 2004, 440-42, 449; Desposato and Petrocik, 2003, 24; Desposato and Petrocik, 2005, 52; McKee, 2008b, 973). When an exchange of constituents takes place between adjoining districts, informal pre-election coordination of casework loads may occur, and same-party members may 
make joint appearances in the parts of the districts slated for transfer (Boatright, 2004, 449).

Less research has been devoted to the topic of identifying the antecedent factors that underlie decisions by line drawers to shift the partisan balance in a district or to retain larger or smaller numbers of a member's old constituents. The most comprehensive work has been done by Yoshinaka and Murphy. They demonstrate that with one-party control of redistricting, both partisanship and intactness tend to be manipulated in favor of the redistricting (i.e., in-) party and against the non-redistricting (i.e., out-) party, while bipartisan and neutral plans have effects on the two parties of intermediate consequence. ${ }^{2}$ More specifically, with regard to out-party incumbents, a partisan plan will generally reduce the number of their fellow party identifiers in marginal districts, at the same time that the number of their identifiers in safe districts is increased in order to waste votes. For in-party incumbents, reductions or increases in the number of fellow party identifiers will occur in safe and marginal districts, respectively. Partisan plans will also maintain the intactness of constituencies represented by in-party members more than that of constituencies held by the opposition, and this difference will be especially pronounced in marginal districts. Furthermore, two environmental factors beyond the control of mapmakers - - greater change in seats resulting from reapportionment, and larger state delegation size - - make for less intactness. The former means more disruption in boundaries than if representation remained the same, while the latter makes it easier to disguise the fact that a party has implemented major self-serving boundary alterations (Yoshinaka and Murphy, 2009, 455).

What is missing in the extant literature, however, is an integrative model that knits together the two separate components of redistricting; i.e., that specifies how the political and environmental antecedent factors, through their prior impacts on district partisanship and intactness, ultimately affect reelection margin. At present, we simply do not know the answers to such questions as the extent to which line drawers' partisan efforts to influence reelection margins by manipulating intactness will succeed in overcoming environmental constraints imposed by change in the number of a state's representatives or by delegation size itself. Nor do we know whether the compound pathways to reelection margin passing through change in district partisanship are more or less efficacious in altering reelection safety than are the compound pathways passing through change in district intactness.

Likewise overlooked in previous work is the potentially important role that another environmental factor - - district population size prior to redistricting - - may play in affecting mapmakers' calculations. In an over-populated district that must be pared down in size to comply with the Supreme Court's mandate of strict population equality among all districts in a state, it is natural to expect that the incumbent would gain relatively few new constituents. At the extreme, population relocation could take the form of only removing the number of excess constituents, resulting in a new district where all constituents had previously been represented by the same member. An under-populated district, on the other hand, necessarily must end up with new constituents whose number, at minimum, equals the extent of its under-population. All in all, district population size prior to redistricting 
should therefore be positively related to the proportion of the member's new district comprised of previously represented constituents.

Besides its influence on intactness, district population size may have a less obvious effect on incumbent safety as well. Forgette and Platt put forth the argument that in districts with population decline since the previous redistricting, incumbents may be less effective making the case to those in charge of redistricting that their reelection fortunes deserve to be safeguarded $(2005,946)$. When the authors enter district population change into a regression equation explaining shifts in the incumbent party's share of the vote from 2000-02, the variable's coefficient is shy of significance, but not by much. However, population change, while certainly related to whether a district will be over- or under-sized, is not the same thing. Consider, for example, a situation where two states maintain stable representation as a result of reapportionment, but where the first has a greater rate of population growth. A district with growth below the statewide average in the first state would thus be under-sized and in need of extra constituents, whereas a district with the same amount of absolute growth but above the statewide average in the second state would be over-sized and in need of population removal. So a given amount of population gain or loss might weigh differently on the minds of line drawers in different states with regard to the sympathy shown toward incumbents' entreaties for extra safety, perhaps accounting for the variable's not having a stronger electoral effect in Forgette and Platt's study.

Furthermore, over-populated districts should in and of themselves provide greater leeway for mapmakers who wish to reconfigure boundaries in a pro-incumbent direction to actually do so. Members from over-sized districts may argue that the necessary population removal should occur mainly in areas with partisan leanings contrary to their own (McDonald, 2004, 373). Mapmakers in these districts can choose from a broader array of areas with concentrations of non-incumbent party voters which ones to shift to other districts.

Thus, the expectation for the model to be developed is that in over-populated compared to under-populated districts, there will be greater intactness and more favorable partisan shifts toward the incumbent's party owing to the redistricting process, with the end consequence being enhancement of incumbent safety. The sorting out of these relationships, as well as the others to be incorporated in the model, will be accomplished through path analysis. The decennial redistricting cycles of 1991-92, 2001-02, and 2011-12 will be examined; for earlier redistrictings, the requisite data on district population transfers are not available from the Geographic Correspondence Engine of the Missouri Census Center (http://mcdc.missouri.edu/webas/geocorr12.html).

\section{A First Look at the Effects of District Intactness and Partisan Change on Reelection Margin}

As the starting point of the analysis prior to undertaking path analysis, we perform OLS regressions in which the effects on incumbents' reelection margin of intactness and change in district partisanship are contrasted. The dependent variable is the incumbent's proportion of the two-party vote in the immediate post-redistricting election, minus the proportion in the election two years earlier. Incumbents who did not encounter major party 
opposition in either of these elections, as well as those who faced off against another incumbent as a result of redistricting, are excluded. ${ }^{3}$ Most previous efforts to analyze the effects of redrawing district lines have simply employed post-redistricting incumbent safety by itself as the dependent variable, ${ }^{4}$ but this can yield misleading estimates when the redrawing of lines is influenced by the incumbent's prior level of safety. Take, for example, a case where a partisan plan attempts to defeat a chronically underperforming incumbent of the non-redistricting party by crafting a new district containing relatively few of his or her original constituents. Post-redistricting reelection margin may in fact end up low, but less because of the damaged intactness than because the incumbent was weak in the first place. Using instead the change in election margin isolates the independent effect of intactness by holding constant unobservable influences on the vote, such as mediocre campaigning aptitude on the part of the incumbent, that are time-invariant. ${ }^{5}$

As indicated, data from the Missouri Census Center's Geographic Correspondence Engine are used to determine a district's level of intactness, which equals the proportion of post-redistricting constituents who were previously represented by the same member. District partisanship is assessed, comporting with standard practice, in terms of the proportion of the two-party vote received by the presidential candidate of the congressional incumbent's party. The district partisan change variable that is entered into the equation subtracts this presidential vote proportion actually recorded in the most recent preredistricting on-year election from the reconfigured vote proportion calculated within the new district lines. Thus, for the 1992, 2002, and 2012 analyses, presidential vote statistics from the 1988 George H. W. Bush-Dukakis race, the 2000 George W. Bush-Gore race, and the 2008 McCain-Obama race, respectively, are employed.

Three control variables also appear in the equations. They are as follows:

Freshman status ( 1 if incumbent in the post-redistricting year is attempting his or her first reelection; 0 for more senior members) ${ }^{6}$

Incumbent's party ( 1 if incumbent is Republican; 0 if Democrat)

Change in incumbent vs. challenger spending (ln(incumbent spending) - $\ln$ (challenger spending) in post-redistricting election, minus $\ln$ (incumbent spending) - $\ln$ (challenger spending) in pre-redistricting election). ${ }^{7}$

The freshman status variable accounts for the likelihood that ceteris paribus, first term members will increase their vote margin as a consequence of gaining the electoral perquisites of incumbency between the two election years. The party of the incumbent is necessary to control for partisan swings in the national congressional vote between elections. Finally, the spending variable incorporates information on both incumbent and challenger expenditures; the latter, according to Desposato and Petrocik, is the best indicator of challenger competitiveness $(2003,26-27){ }^{8}$ By calculating the natural logs of both incumbent and challenger expenditures, increasing levels of campaign spending are allowed to have diminishing returns on electoral outcomes. ${ }^{9}$ (All spending is in 1990 
constant dollars.) Even though at this starting point in the analysis spending is being treated as an exogenous variable, we recognize its potential endogeneity; e.g., the possibility that an anti-incumbent shift in district partisanship will spur greater contributions to the challenger. This possibility, along with the endogeneity of district partisan change and intactness, will be incorporated into the subsequent path analysis that we perform.

As a second specification, we add an independent variable singling out states employing redistricting commissions to redraw constituency boundaries:

Commission ( 1 for commission states; 0 otherwise). ${ }^{10}$

Advocates of commission-style redistricting oftentimes argue that it is less likely to yield incumbent-friendly outcomes; in fact, some commissions (e.g., Arizona's) are required by state law to emphasize crafting competitive districts. Bullock, however, points out in his examination of two states employing this technique during the 2001-02 redistricting cycle that inter-election competition grew in Iowa, but not in Arizona (2010, 132-37).

Favorable shifts in district partisanship, of course, consistently have highly significant effects on change in incumbent safety, and the magnitude of the effect, as gauged by the unstandardized regression coefficients, grows over time in line with the well-documented rise in the importance of partisan voting (Abramowitz, 2010, 95-96; Jacobson, 2011, 44). Greater intactness likewise acts consistently to promote safety, even though the coefficient in 1992 is slightly shy of the one-tail, $\mathrm{p}<.05$ level of significance. ${ }^{11}$ With regard to the control variables, freshman status and campaign spending differentials have, as expected, positive impacts on safety, and Republicans in 2002 and, even more strongly, Democrats in 2012 benefit from national electoral swings in the direction of their party. Estimation of the second model, of course, shows that the commission system of redistricting makes no difference on change in reelection margins. In the more comprehensive path analysis to follow, however, we shall consider commission-based plans in combination with other non-partisan plans in order to sort out their antecedent effects on the intactness and partisanship change variables themselves. 
Table 1. OLS Regression of Changes in House Incumbent's Reelection Margin on Post-Redistricting Intactness and Change in Partisanship of District

\begin{tabular}{|c|c|c|c|c|c|c|}
\hline \multirow[b]{3}{*}{$\begin{array}{l}\text { District } \\
\text { Intactness }\end{array}$} & \multicolumn{2}{|c|}{1992} & \multicolumn{2}{|c|}{2002} & \multicolumn{2}{|c|}{2012} \\
\hline & Model 1 & Model 2 & Model 1 & Model 2 & Model 1 & Model 2 \\
\hline & $\begin{array}{c}034(.022) \\
(.080)\end{array}$ & $\begin{array}{c}.035 \quad(.022) \\
(.082)\end{array}$ & $\begin{array}{c}.035^{* *}(.013) \\
(.098)\end{array}$ & $\begin{array}{c}.036^{* *}(.013) \\
(.100)\end{array}$ & $\begin{array}{c}.030 * *(.011) \\
(.084)\end{array}$ & $\begin{array}{c}.034 * *(.011) \\
(.093)\end{array}$ \\
\hline $\begin{array}{l}\text { District Partisan } \\
\text { Change }\end{array}$ & $\begin{array}{c}.658 * * *(.099) \\
(.347)\end{array}$ & $\begin{array}{c}.657 * * *(.099) \\
(.346)\end{array}$ & $\begin{array}{c}.881 * * *(.076) \\
(.468)\end{array}$ & $\begin{array}{c}.882 * * *(.076) \\
(.469)\end{array}$ & $\begin{array}{c}.956 * * *(.061) \\
(.524)\end{array}$ & $\begin{array}{c}.955^{* * *}(.061) \\
(.524)\end{array}$ \\
\hline $\begin{array}{l}\text { Freshman } \\
\text { Status }\end{array}$ & $\begin{array}{c}.036 * *(.013) \\
(.146)\end{array}$ & $\begin{array}{c}.037 * *(.013) \\
(.151)\end{array}$ & $\begin{array}{c}.046 * * *(.008) \\
(.217)\end{array}$ & $\begin{array}{c}.046 * * *(.008) \\
(.218)\end{array}$ & $\begin{array}{c}.031 * * *(.006) \\
(.180)\end{array}$ & $\begin{array}{c}.031 * * *(.006) \\
(.183)\end{array}$ \\
\hline $\begin{array}{l}\text { Incumbent's } \\
\text { Party }\end{array}$ & $\begin{array}{c}.008(.009) \\
(.046)\end{array}$ & $\begin{array}{c}.008(.009) \\
(.047)\end{array}$ & $\begin{array}{c}.032 * * *(.005) \\
(.243)\end{array}$ & $\begin{array}{c}.032 * * *(.005) \\
(.244)\end{array}$ & $\begin{array}{c}-.089 * * *(.005) \\
(-.590)\end{array}$ & $\begin{array}{c}-.089 * * *(.005) \\
(-.588)\end{array}$ \\
\hline $\begin{array}{l}\text { Change in } \\
\text { incumbent vs. } \\
\text { challenger } \\
\text { spending }\end{array}$ & $\begin{array}{c}.017 * * *(.003) \\
(.360)\end{array}$ & $\begin{array}{c}.017 * * *(.003) \\
(.357)\end{array}$ & $\begin{array}{c}.012 * * *(.001) \\
(.355)\end{array}$ & $\begin{array}{c}.012 * * *(.001) \\
(.354)\end{array}$ & $\begin{array}{c}.011 * * *(.001) \\
(0.266)\end{array}$ & $\begin{array}{c}011 * * *(.001) \\
(.267)\end{array}$ \\
\hline Commission & --- & $\begin{array}{c}.023(.017) \\
(.067)\end{array}$ & --- & $\begin{array}{c}-.007 \quad(.007) \\
(-.032)\end{array}$ & --- & $\begin{array}{c}.007(.006) \\
(.035)\end{array}$ \\
\hline Constant & $-.036^{*}(.018)$ & $-.039 *(.018)$ & $-.050 * * *(.011)$ & $-.050 * * *(.011)$ & $.020 * \quad(.008)$ & $.016 \quad(.009)$ \\
\hline $\begin{array}{l}\text { Number of } \\
\text { Observation }\end{array}$ & 252 & 252 & 270 & 270 & 300 & 300 \\
\hline $\mathrm{R}^{2}$ & 0.372 & 0.376 & 0.648 & 0.649 & 0.738 & 0.739 \\
\hline & $\begin{array}{l}\text { Note: Entries on } \\
\text { Entries in paren } \\
{ }^{* * *} \text { Significant at } \\
\text { tail t-test). }\end{array}$ & $\begin{array}{l}\text { irst line are unsta } \\
\text { eses on second } \\
01 \text { level (one-tail }\end{array}$ & $\begin{array}{l}\text { Aardized regressio } \\
\text { are standardized } \\
\text { test) }{ }^{* *} \text { significant }\end{array}$ & $\begin{array}{l}\text { coefficients, with } \\
\text { 3) regression coeff } \\
\text {.01 level (one-tail }\end{array}$ & $\begin{array}{l}\text { andard errors in } \\
\text { ients. } \\
\text {-test); *significan }\end{array}$ & $\begin{array}{l}\text { rentheses. } \\
.05 \text { level (one- }\end{array}$ \\
\hline
\end{tabular}

Finally, the magnitudes of the standardized $(\beta)$ coefficients indicate that change in partisanship makes much more electoral difference than does the proportion of constituents in the new district previously represented by the member. The ratios vary from a 4.2:1 advantage for partisan change in the second 1992 model to a 6.2:1 advantage in the first 2012 model. Presumably, some of this comparative weakness in the explanatory power of district intactness is, as mentioned above, a function of the heightened efforts made by incumbents to solicit support from their newly appended areas.

Of course, we have not yet differentiated between the portion of each of these two redistricting-based changes that is determined by environmental factors beyond the control of line drawers like district population, and the portion that is determined by the political decisions of line drawers themselves. It is toward this goal that we turn in the next section, which develops the path analysis model. ${ }^{12}$ 


\section{The Path Analysis Model}

Of the five independent variables used in the previous Model 1 equations, all but freshman status and party are treated as endogenous in the path analysis model to be estimated. The antecedent variables that have been added to the model, hypothesized to affect change in election margin indirectly through their direct effects on district partisan change and intactness, are operationalized as follows:

Party control (\#1) (3 for marginal districts of redistricting party or for safe districts of non-redistricting party; 2 for districts in states with bipartisan or court imposed redistricting plan; 1 for safe districts of redistricting party or for marginal districts of non-redistricting party)

Party control (\#2) (5 for marginal districts of redistricting party; 4 for safe districts of redistricting party; 3 for districts in states with bipartisan or courtimposed redistricting plan; 2 for safe districts of non-redistricting party; 1 for marginal districts of non-redistricting party) ${ }^{13}$

District over-/under-population (district's pre-redistricting population minus its post-redistricting population, divided by post-redistricting population)

Size of state delegation (number of House districts after redistricting)

Change in state delegation size (absolute value of change in number of House districts resulting from reapportionment).

The arguments for why these factors should be causes of district partisan change and/or intactness, of course, were set forth above in the opening section of the paper where we discussed the work of Yoshinaka and Murphy and our own argument that a district population variable is needed to better specify the model. The two operationalizations related to the partisanship of the redistricting plan are responsive to the different ways in which they find that district partisan change and intactness are affected by such partisanship.

Yoshinaka and Murphy's codification of the specific party favored by each plan, which they employ in their study of 2001-02 redistricting, differs from ours, however. Their scheme is borrowed from McDonald (2004, 385-91), who appraises the deliberations surrounding each state's redistricting process that cycle to gauge the partisan intentions of those devising district lines, which may imperfectly relate to actual party control of the process. We instead employ the classification scheme of Friedman and Holden that has the virtue, they argue, of obviating the need to make subjective judgments about intentions (2009, 598). They classify decennial and out-of-cycle redistrictings occurring from 1971-72 to 2003-04 (and we follow suit for 2011-12) as follows: Partisan (where a single party controls all relevant institutions of state government), Bipartisan (where single-party control of these institutions does not exist), and Court Ordered (where judges have devised the final plan). We have collapsed together bipartisan and court ordered plans to form a single category, since both treat a state party less positively than when its own mapmakers are in command, but more positively than when there is an opposition-controlled plan. ${ }^{14}$ 
As a test of our classification scheme in 2001-02, the redistricting cycle for which McDonald's measure is available, we contrast how well the measures do when they are correlated with district partisan change and intactness. Our own measure in both cases yielded somewhat stronger correlations. The $r$ between the partisanship of the plan and partisan change is .26 with our measure compared to an $r$ of .24 when McDonald's classification scheme is used; for the correlation between the partisanship of the plan and intactness, the r's are .17 and .13 , respectively.

Aside from introducing the antecedent variables as causes of change in partisanship and intactness in the path diagram, we also allow for the variable tapping change in spending to be endogenous. The expectation is that district partisan shifts favoring the incumbent's party, in addition to smaller influxes of new constituents, should make challengers worse investments in the eyes of potential contributors, thus inflating incumbents' expenditures relative to those of the challenger. Likewise, an inter-election transition from non-incumbent to freshman status should amplify this spending advantage, since the investment potential of an opponent would be less in the second election when the formidable electoral advantages of incumbency had to be overcome.

As the final step in performing the path analysis, Lagrange Multiplier modification indices were examined to determine whether any further linkages beyond those already mentioned would significantly improve the overall model fit. None was required in the 1992 analysis. In 2002, however, a link was needed extending from change in partisanship to intactness; the negative sign of the link indicates that creating more incumbent-friendly partisanship led to the addition of greater numbers of new constituents. Inspection of the 2012 modification indices prompted incorporation of a negatively-signed link from the party of the incumbent to change in incumbent versus challenger spending, and a positively- signed link from freshman status to change in district partisanship. The former is readily understood in terms of aggressive Democratic fundraising initiatives in 2012 against Republican incumbents to help the party rebound from its electoral debacle two years earlier. The latter makes sense in light of the confluence of heavy Republican control of redistricting across the nation and the many switched-seat GOP freshmen whose districts needed partisan shoring up for 2012.

Figures 1, 2, and 3 display the complete path analysis models we have estimated for 1992, 2002, and 2012. In each model, of course, there are four separate path equations for the endogenous variables of change in incumbent reelection margin, district intactness, change in district partisanship, and change in incumbent versus challenger spending, respectively. To alleviate clutter, curved double-headed arrows, sometimes drawn in path analysis diagrams to represent covariances among the exogenous variables, are omitted, even though these covariances have been computed as part of the model estimation. We also omit from the diagrams the error terms calculated as part of the endogenous variable equations and the variance estimates for the exogenous variables. Maximum likelihood estimation using the CALIS procedure of SAS has been employed to generate the parameters. Standardized path coefficients appear, resulting from analysis of the correlation matrix. 
Three measures of the overall fit of each model to the data are provided in the diagrams. All are at the conventional levels for acceptable fit (Hu and Bentler, 1999, 27-28). The Goodness of Fit Index, equaling the proportion of variance in the variancecovariance matrix explained by the model, and the Bentler Comparative Fit Index, contrasting the model with the independence model in which no paths exist between variables, consistently exceed .95. The Root Mean Square Error of Approximation, comparing the model to the saturated model in which direct paths connect each variable with all others, is uniformly below .06 . 


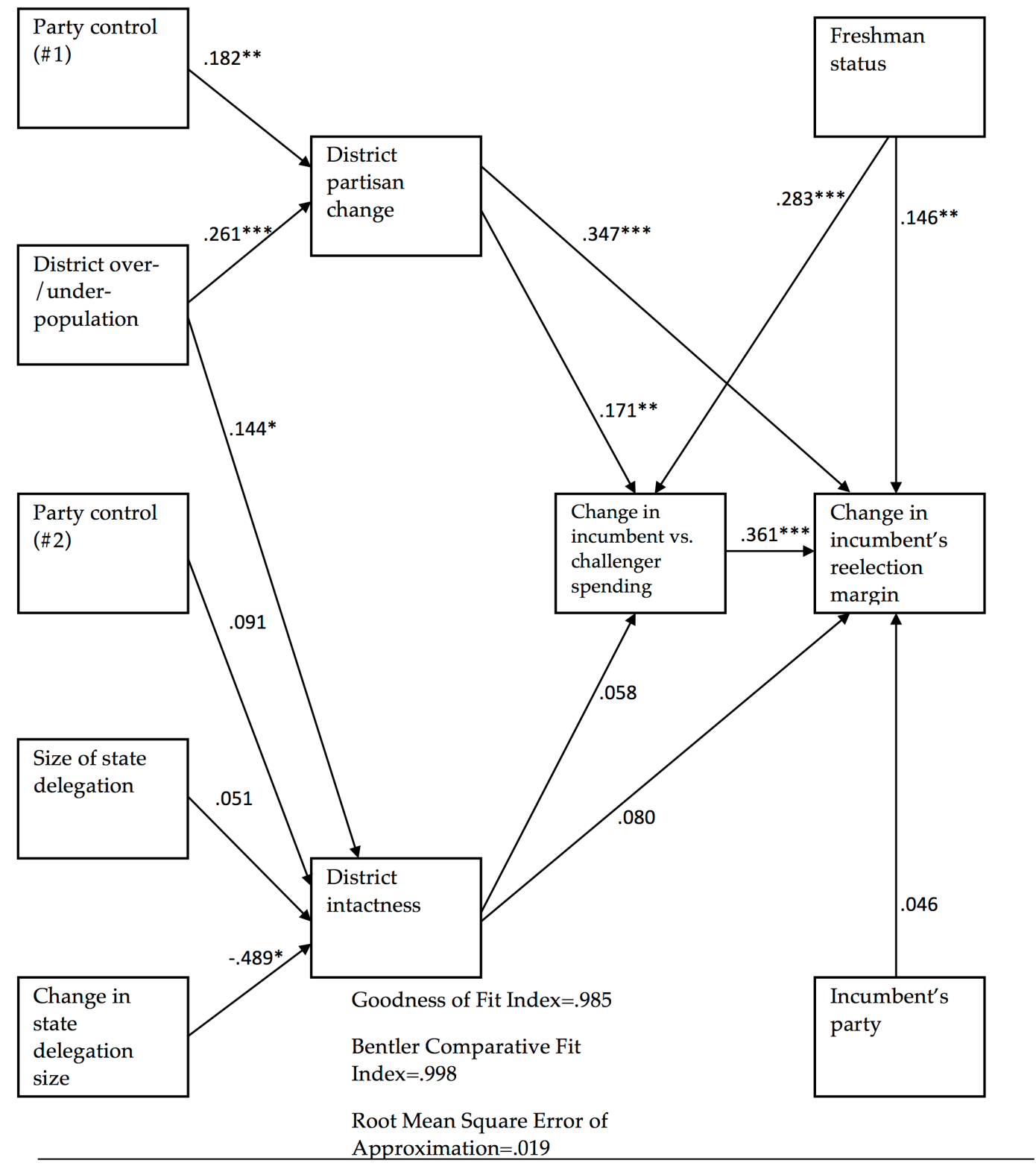

Note: All entries are standardized $(\beta)$ path coefficients.

${ }^{* * *}$ Significant at .001 level (one-tail t-test); ${ }^{* *}$ significant at .01 level (one-tail t-test); ${ }^{*}$ significant at .05 level (one-tail t-test). 


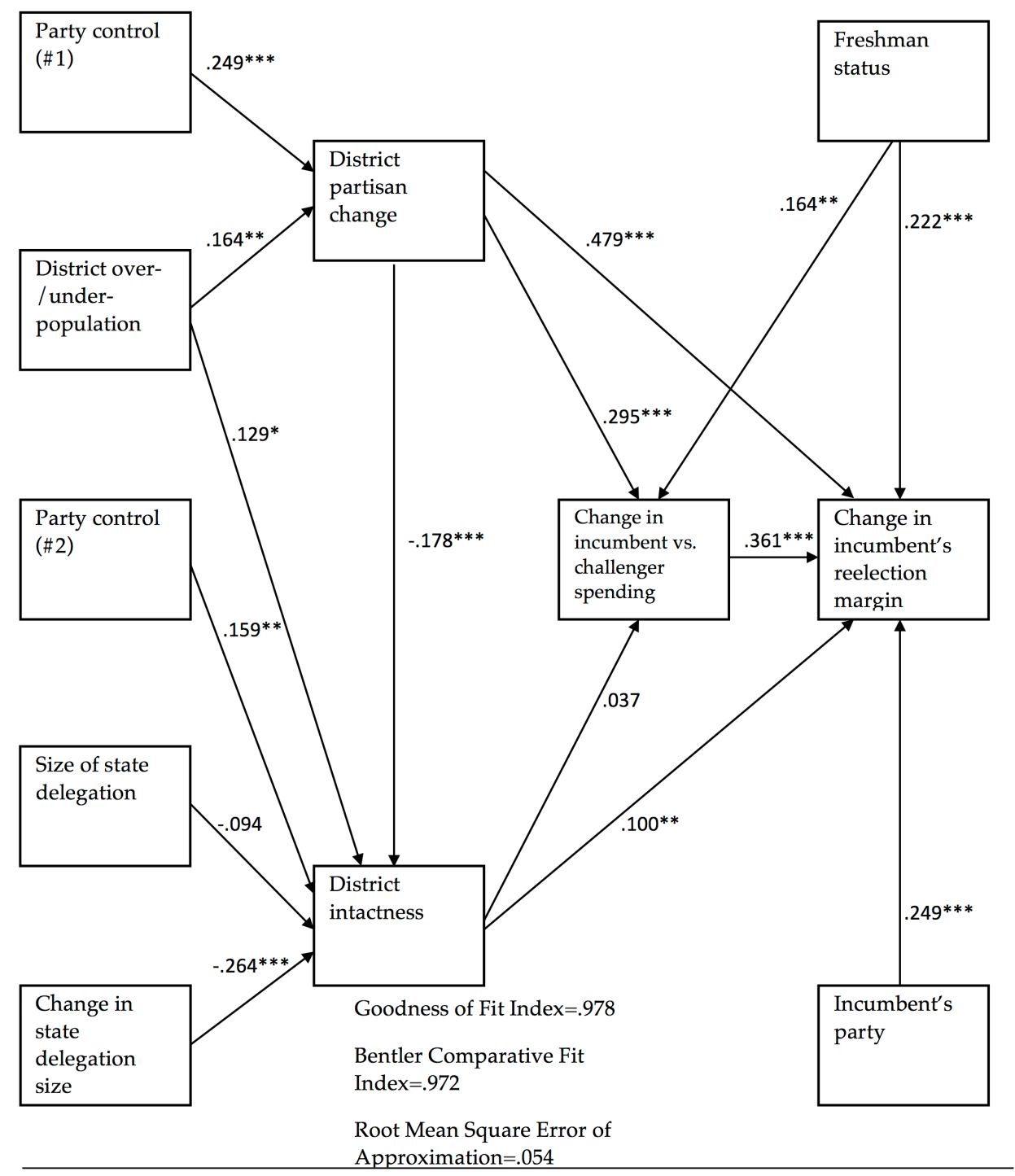

Note: All entries are standardized $(\beta)$ path coefficients.

${ }^{* * *}$ Significant at .001 level (one-tail t-test); ${ }^{* *}$ significant at .01 level (one-tail t-test); ${ }^{*}$ significant at .05 level (one-tail t-test). 
PATH ANALYSIS OF REDISTRICTING EFFECTS ON

CHANGES IN REELECTION MARGIN, 2012

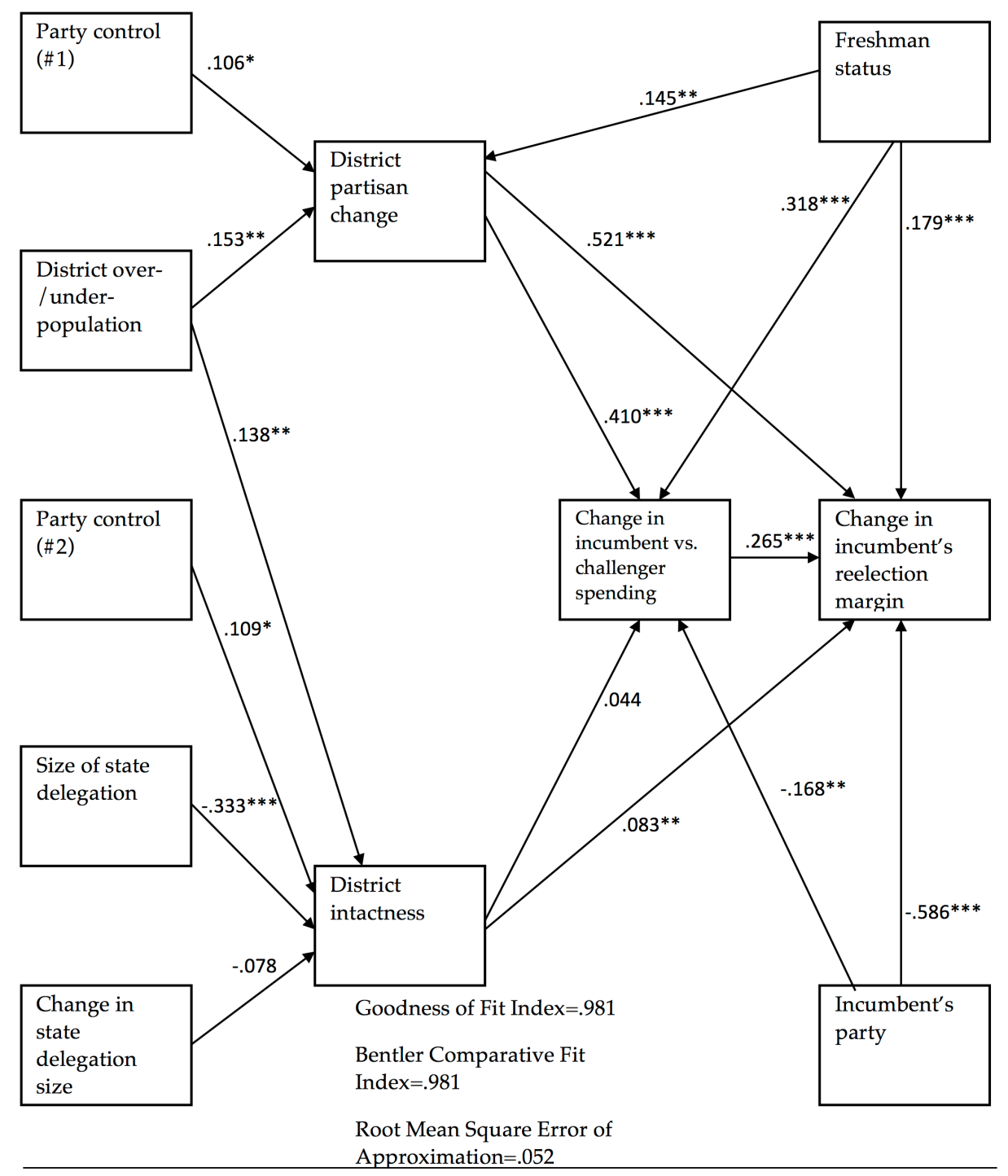

Note: All entries are standardized $(\beta)$ path coefficients.

${ }^{* * *}$ Significant at .001 level (one-tail t-test); ${ }^{* *}$ significant at .01 level (one-tail t-test); ${ }^{*}$ significant at .05 level (one-tail t-test). 
The first path coefficients we focus on involve district over-/under-population. It is clear from the positive signs of these coefficients that in districts over-populated prior to redistricting, partisanship, as hypothesized, tends to be shifted in an pro-incumbent direction. All three standardized coefficients in Figures 1-3 are significant at least at the $p<$. 01 level. Furthermore, over-populated districts, again as hypothesized, tend to end up with a smaller proportion of new constituents, as indicated by the significantly positive signs of the coefficients. What is surprising about the magnitudes of the coefficients, however, is that this seemingly obvious relationship is relatively weak, always falling short of the effect that the population variable has on partisan change. We shall shortly have more to say about this peculiar finding after appraising the remaining parts of the model.

Other paths leading to the endogenous variables are generally compatible with expectations as well. The two variables dealing with party control of the redistricting process have significant effects on district partisan change and intactness five of six times. Larger campaign finance disparities between incumbents and challengers are regularly prompted by district partisan change favoring the incumbent's party and by the attainment of freshman status. On the other hand, greater numbers of new constituents never significantly affect spending disparity, a result dovetailing with the finding that district intactness has weaker effects on reelection margin than does change in partisanship. From the standpoint of potential contributors, why should investments in a challenger grow in league with drops in district intactness if decreased intactness does not more strongly reduce reelection odds? ${ }^{15}$ Finally, districts in states undergoing alteration in delegation size experience less intactness in 1992 and 2002, while districts in larger states experience less intactness only in 2012 . $^{16}$

The remaining path analysis results entail calculation of the total effects that the antecedent variables have on reelection margin through all pathways by which such influence can be exerted. This requires multiplying together the standardized coefficients of all individual paths making up a compound path (Bollen, 1989, 36-38; Loehlin, 2004, 8-10). In 1992, for example, the total effects of district over-/under-population on reelection margin associated with district partisan change are $.261 \mathrm{x} .347=.091$ for the effect routed solely through partisan change, plus $.261 \times .171 \times .361=.016$ for the effect routed sequentially through partisan change and then campaign spending. These total effects appear in Tables 2, 3, and 4. 
Table 2. Effects of Antecedent Variables on Change in Incumbent's Reelection Margin, 1992

Effect of party control (\#1) routed through district partisan change alone, plus effect of party control (\#1) routed sequentially through district partisan change \& change in incumbent vs. challenger spending

Effect of party control (\#2) routed through district intactness alone, plus effect of party control (\#2) routed sequentially through district intactness $\&$ change in incumbent vs. challenger spending

Overall effects of party control (\#1) \& (\#2)

Effect of District over-/under-population routed through District partisan change alone, plus effect of District over-/under-population routed sequentially through District partisan change \& Change in incumbent vs. challenger spending

Effect of District over-/under-population effect routed through District intactness alone, plus effect of District over-/under-population effect routed sequentially through District intactness \& Change in incumbent vs. challenger spending

Overall effects of District over-/under-population

Effect of Size of state delegation routed through District intactness alone, plus effect of Size of state delegation routed sequentially through District intactness \& Change in incumbent vs. challenger spending (i.e., Overall effects of Size of state delegation)

Effect of Change in state delegation size routed through

$-.039-.010=-.049$
$.063+.011=.074$

$.007+.002=.009$
$.091+.016=.107$

$.012+.003=.015$

$.107+.015=.122$

$.004+.001=.005$

District intactness alone, plus effect of Change in state delegation size routed sequentially through District intactness \& Change in incumbent vs. challenger spending (i.e., Overall effects of Change in state delegation size)

Note: All calculations based upon standardized path coefficients from Figure 1. 
Table 3. Effects of Antecedent Variables on Change in Incumbent's Reelection Margin, 2002

\begin{tabular}{|c|c|}
\hline $\begin{array}{l}\text { Effect of party control (\#1) routed through district } \\
\text { partisan change alone, plus effect of party control (\#1) } \\
\text { routed sequentially through district partisan change \& } \\
\text { change in incumbent vs. challenger spending }\end{array}$ & $.119+.027=.146$ \\
\hline $\begin{array}{l}\text { Effect of party control (\#2) routed through district } \\
\text { intactness alone, plus effect of party control (\#2) routed } \\
\text { sequentially through district intactness \& change in } \\
\text { incumbent vs. challenger spending }\end{array}$ & $.016+.002=.018$ \\
\hline Overall effects of party control (\#1) \& (\#2) & $.146+.018=.164$ \\
\hline $\begin{array}{l}\text { Effect of district over-/under-population routed through } \\
\text { district partisan change alone, plus effect of district } \\
\text { over-/under-population routed sequentially through } \\
\text { district partisan change \& change in incumbent vs. } \\
\text { challenger spending }\end{array}$ & $.079+.017=.096$ \\
\hline $\begin{array}{l}\text { Effect of district over-/under-population effect routed } \\
\text { through district intactness alone, plus effect of district } \\
\text { over-/under-population effect routed sequentially } \\
\text { through district intactness \& change in incumbent vs. } \\
\text { challenger spending }\end{array}$ & $.013+.002=.015$ \\
\hline Overall effects of district over-/under-population & $.096+.015=.111$ \\
\hline $\begin{array}{l}\text { Effect of size of state delegation routed through district } \\
\text { intactness alone, plus effect of size of state delegation } \\
\text { routed sequentially through district intactness \& change } \\
\text { in incumbent vs. challenger spending (i.e., overall } \\
\text { effects of size of state delegation) }\end{array}$ & $-.009-.001=-.010$ \\
\hline $\begin{array}{l}\text { Effect of change in state delegation size routed through } \\
\text { district intactness alone, plus effect of change in state } \\
\text { delegation size routed sequentially through district } \\
\text { intactness \& change in incumbent vs. challenger } \\
\text { spending (i.e., overall effects of change in state } \\
\text { delegation size) }\end{array}$ & $-.026-.004=-.030$ \\
\hline
\end{tabular}

Note: All calculations based upon standardized path coefficients from Figure 2. 
Table 4. Effects of Antecedent Variables on Change in Incumbent's Reelection Margin, 2012

\begin{abstract}
Effect of party control (\#1) routed through district partisan change alone, plus effect of party control (\#1) routed sequentially through district partisan change $\&$ change in incumbent vs. challenger spending
\end{abstract}

Effect of party control (\#2) routed through district intactness alone, plus effect of party control (\#2) routed sequentially through district intactness \& change in incumbent vs. challenger spending

Overall effects of party control (\#1) \& (\#2)

Effect of district over-/under-population routed through district partisan change alone, plus effect of district over-/under-population routed sequentially through district partisan change \& change in incumbent vs. challenger spending

Overall effects of district over-/under-population

Effect of size of state delegation routed through district intactness alone, plus effect of Size of state delegation routed sequentially through district intactness $\&$ change in incumbent vs. challenger spending (i.e., overall effects of size of state delegation)

Effect of change in state delegation size routed through district intactness alone, plus effect of change in state delegation size routed sequentially through district intactness \& change in incumbent vs. challenger spending (i.e., overall effects of change in state delegation size)
$.055+.012=.067$

$.009+.001=.010$
$.067+.010=.077$

$.080+.017=.097$

$.097+.013=.110$

$-.028-.004=-.032$

$-.006-.001=-.007$

Note: All calculations based upon standardized path coefficients from Figure 3. 
Two conclusions stand out. First, the district population and party control antecedent variables make more of a reelection difference by means of their paths passing through district partisan change than via the alternative paths passing through intactness. ${ }^{17}$ This obviously is largely a function of the much greater force that partisan change exerts through its direct path to reelection margin, as well as its greater indirect force transmitted through the incumbent-challenger spending differential. In smaller part, however, it is also because the antecedent variables more strongly affect partisan change than they do intactness, except in 2012 when the two impacts of party control are of similar magnitude.

Second, the overall effects on reelection margin of district population are stronger than those of party control in 1992 and 2012. Thus, a factor independent of the mapmakers has more influence on incumbents' reelection fortunes than does party control of the redistricting plan. And when the additional effects of delegation size and change in delegation size - - two other antecedent factors outside the control of mapmakers - - are taken into account, it becomes even more striking that environmental factors trump political factors in these two years.

We return now to the question of why the link between district over-/under-population and intactness is not more robust, despite the fact that the amount of population deficit in an under-sized district dictates the number of new constituents that at minimum must be tacked on, whereas new constituents must be appended to an overpopulated district only to the extent that the number of those removed, if any, exceeds the amount of its over-population. Table 5 sheds light on this question. Here, within the categories of over- and under-populated districts, the actual number of constituents removed by redistricting (normalized in terms of the post-redistricting population) is computed relative to the minimum proportion that must be removed. ${ }^{18}$ For under-populated districts, of course, the minimum removal proportion is zero; for over-populated districts, the minimum removal proportion is the value of the district over-/under-population variable itself.

Table 5 shows that the mean proportion of constituents actually removed from over-sized districts, quite naturally, is always larger than the proportion actually removed from under-sized districts. Notably, however, in over-populated districts line drawers go beyond the minimum displacement levels by greater amounts. Differences between actual and minimum removal levels in over-sized districts are larger than the corresponding differences in under-sized districts by amounts ranging from .026 in the 2001-02 redistricting cycle (i.e., .197 - .171) to .091 in 1991-92 (i.e., .238 - .147). So the consequence of this extra measure of aggressiveness in removing constituents from overpopulated districts is the concomitant need to bring in more new constituents as compensation, which in turn means that the intactness of over-populated districts will be smaller than it otherwise would be. Thus, mean intactness levels, which appear as the fourth lines of entries in Table 5, tend to be rather similar across the two types of districts. Only in the 2001-02 redistricting cycle does a t-test of difference between the means result in significance $(\mathrm{p}<.05$, one-tail test). 
Table 5. Mean Proportions of Constituents Removed from Under-populated and Over-populated Districts

\begin{tabular}{|c|c|c|c|}
\hline & $\begin{array}{l}\text { 1991-1992 } \\
\text { Redistricting Cycle }\end{array}$ & $\begin{array}{l}\text { 2001-2002 Redistricting } \\
\text { Cycle }\end{array}$ & $\begin{array}{l}\text { 2011-2012 Redistricting } \\
\text { Cycle }\end{array}$ \\
\hline \multicolumn{4}{|l|}{ Under-Populated Districts } \\
\hline $\begin{array}{l}\text { Minimum Proportion of } \\
\text { Constituents Necessary for } \\
\text { Removal }\end{array}$ & .0 & .0 & .0 \\
\hline $\begin{array}{l}\text { Actual Proportion of } \\
\text { Constituents Removed }\end{array}$ & .15 & .17 & .21 \\
\hline $\begin{array}{l}\text { Excess of Actual Proportion of } \\
\text { Constituents Removed over } \\
\text { Minimum Proportion }\end{array}$ & .15 & .17 & .21 \\
\hline District Intactness & .77 & .76 & .72 \\
\hline Number of Districts & 134 & 158 & 187 \\
\hline \multicolumn{4}{|l|}{ Over-Populated Districts } \\
\hline $\begin{array}{l}\text { Minimum Proportion of } \\
\text { Constituents Necessary for } \\
\text { Removal }\end{array}$ & .13 & .1 & .11 \\
\hline $\begin{array}{l}\text { Actual Proportion of } \\
\text { Constituents Removed }\end{array}$ & .37 & .3 & .38 \\
\hline $\begin{array}{l}\text { Excess of Actual Proportion of } \\
\text { Constituents Removed over } \\
\text { Minimum Proportion }\end{array}$ & .24 & .2 & .27 \\
\hline District Intactness & .76 & .8 & .73 \\
\hline Number of Districts & 118 & 112 & 113 \\
\hline
\end{tabular}

Note: Calculations based upon all districts employed in path analyses of Figures 1-3.

The outsized removal rates found in over-populated districts likewise bear upon the accompanying question of why these districts' partisanship tends to shift in a proincumbent direction. As mentioned on pages 48, line drawers should be more favorably predisposed toward the entreaties of incumbents from over-sized districts for safer seats, and they can more easily deliver upon these predispositions because of the greater leeway afforded by such districts to remove constituents with partisanship opposite the incumbent's. Table 6 examines whether dislodged constituents, in fact, disproportionately have anti-incumbent partisan leanings. Here, the only accessible data that permit the question to be addressed are at the individual level, rather than the district-level data we have been analyzing up to this point. Two ANES panel studies are employed: the 1990-1991-1992 Full Panel File, and the 2000-2002-2004 Full Panel File. No comparable panel study exists to allow identification of which respondents from 2010 to 2012 were 
retained in the same district and which were transferred to a new district, so the analysis must be restricted to the first two redistrictings only.

The dependent variable in the individual-level analysis equals 1 for constituents who are transferred out of an incumbent's district, and 0 for those who remain. Five independent variables appear in the equations:

Pre-redistricting presidential vote (1 for respondents whose presidential vote in 1988 (2000) was against the party holding the House seat in 1992 (2002); 0 otherwise) ${ }^{19}$

District over-/under-population (defined as before)

Size of state delegation (defined as before)

Change in state delegation size (defined as before)

Race (1 for African-American respondents; 0 otherwise).

Pre-redistricting presidential vote, the central independent variable, should have a positive coefficient if, indeed, there is a tendency for mapmakers to strengthen incumbents by removing constituents who have been supporters of the non-incumbent party. It is, of course, the individual-level analogue of the district-level presidential vote variable that we earlier used to tap district partisanship. Greater pre-redistricting district population, larger state delegation size, and change in state delegation size should also make it more likely that a constituent will be moved into a new district. Finally, the race variable, also expected to have a positive coefficient, is included because of the drive to pack together AfricanAmericans within the boundaries of new majority minority districts, especially in 1991-92.

Table 6 contains the probit coefficients resulting from this analysis. For both analyses, respondents whose previous presidential vote was at odds with the party of the House incumbent representing them at the time of redistricting are indeed more likely to be shifted to a different district for the next election (the 2001-02 coefficient is just shy of the conventional significance level; i.e., $\mathrm{p}<.059$ ). Respondents from larger districts likewise have a greater chance both times of being transferred, as do African-Americans in 1991-92. Constituent removal, therefore, tends to make underlying district partisanship more friendly toward the incumbent. And there is more potential for such partisanship-enhancing effect in over-sized districts because, as we have shown, line drawers engage even more aggressively in this practice than warranted by the amount of population surplus alone. ${ }^{20}$

\section{Summary and Conclusions}

In this study, we have synthesized the two different components of the redistricting process: the influence of the antecedent variables that determine House districts' intactness levels and changes in partisanship, and the subsequent effects that intactness and partisan change have on incumbents' reelection margins. The path analysis demonstrates, on the whole, that the environmental forces confronting line drawers ultimately make more difference on reelection outcomes than do the politics of the redistricting process itself; i.e., party control of the redistricting plan. District over- or under-population prior to redistricting, an environmental variable that has been slighted in past research, has the strongest overall effects of any antecedent variable on reelection margin in 1992 and 2012. 
Table 6. Probit Analysis of Whether Respondents Transferred Out of House Incumbent's District by Redistricting Voted Against Presidential Candidate of Incumbent's Party in Pre-Redistricting Election

\begin{tabular}{|l|l|l|}
\hline & $1991-1992$ Redistricting Cycle & $2001-2002$ Redistricting Cycle \\
\hline Pre-redistricting presidential vote & $.341^{*}(.166)$ & $.189 \quad(.121)$ \\
\hline District over-/under-population & $1.812^{* *}(.678)$ & $.948^{*}(.571)$ \\
\hline Size of state delegation & $.041 \quad(.027)$ & $.005 \quad(.005)$ \\
\hline Change in state delegation size & $-.128(.180)$ & $.145 \quad(.090)$ \\
\hline Race & $.635 * *(.244)$ & $-.236 \quad(.230)$ \\
\hline Constant & $1.760 * * *(.221)$ & $1.101 * * *(.115)$ \\
\hline Number of observations & 406 & 577 \\
\hline-2 Log Likelihood & $296.62 * * *$ & $483.26 *$ \\
\hline
\end{tabular}

Note: Entries are probit coefficients, with standard errors in parentheses. 2001-02 results have been weighted. ***Significant at .001 level (one-tail t-test); **significant at .01 level (one-tail t-test); *significant at .05 level (onetail t-test).

And even in 2002, when party control made the greatest difference, the combined overall effects of district population, plus the other two environmental factors of delegation size and change in delegation size, come close to equaling the overall effects of party control.

The other major finding from the path analysis is that the pathways operating through changes in the partisan makeup of districts have greater impact on reelection margin than do the pathways operating through intactness. For the most part, this stems from the much larger direct effect on reelection margin exerted by partisan change. But it also stems from the fact that the antecedent variables - - including, rather unexpectedly, district population - - tend to be more strongly related to partisan change than to intactness, and that partisan change makes more difference on the spending gap between incumbents and challengers than does intactness.

This verdict on the relative impotency of intactness, however, shortchanges its relevance in another sense. Our analysis has highlighted the weakness of interrelationships occurring along the intactness pathways, relative to the comparable interrelationships along the partisanship pathways. The analysis did not address, however, the question of the average magnitudes of intactness and partisan change that members actually experience. Obviously, the forces affecting intactness almost always will leave incumbents with districts in which they did not previously represent at least some proportion of the new constituents. This is a critical distinction when set against changes made to district partisanship, which can leave the district either more incumbent-friendly or less incumbent-friendly.

In fact, incumbents had to face considerable numbers of new constituents: mean proportions were $.233, .222$, and .277 in 1992, 2002, and 2012, respectively. By way of contrast, the balance of positive and negative changes in partisanship across all 
constituencies left the average district's partisan slant unaltered or modestly more proincumbent: .002, .006, and .000, respectively. To get an idea of how the average member's reelection margin was consequently affected by redistricting, we can multiply these mean intactness and partisan change values by the relevant unstandardized path coefficients resulting from the path analyses conducted above. (The complete unstandardized path coefficients for Figures 1, 2, and 3 are available by request.) Compared to being left with a completely intact district, a member experiencing the average level of intactness could expect to lose about 1 percent of the vote solely due to this factor in each of the three elections, whereas compared to being left with a district that had no partisan change, the average member's expected vote shift would vary from 0 (2012) to plus .6 percent (2002). ${ }^{21}$ So in this sense, the intactness factor demands attention, since from the standpoint of the average member, there actually is somewhat more to worry about regarding its role in the redistricting process. 


\section{Endnotes}

${ }^{1}$ Hayes and McKee point out as well that some of the damage done to incumbents by redistricting is caused by a disproportionate tendency of new constituents to abstain in the House election, rather than to actually vote against the member $(2009,1013-18)$.

2 Bipartisan plans attempt to help incumbents of both parties, while neutral plans are not intended to help or hurt incumbents of either party.

3 Cases where two or more candidates from the same party appeared on the ballot in either election of the pair, which were possible under the "jungle"/"blanket" primary systems employed by Louisiana in all three redistricting cycles and by California in the last cycle, are excluded from the analysis.

4 The two prominent exceptions that have employed change scores are the Forgette and Platt article discussed above (2005, 943-47), and Crespin (2005, 257-59).

5 See Liker, Augustyniak, and Duncan (1985) and Allison (1990,11-12) for more extended discussions of the advantages that inhere in using this "first differences" approach.

${ }^{6}$ Freshmen who won their seat in a special election are not included in the analysis, since there were no data available from the previous general election with which to construct their score on the electoral change dependent variable. Using their special election margin as the t-1 variable would pose a problem, in that this margin may not be influenced by the same national forces that influenced the vote in the prior general election.

${ }^{7}$ In cases where freshmen were running in the post-redistricting election, the variable becomes $\ln$ (incumbent spending) - $\ln$ (challenger spending) in post-redistricting election, minus $\ln$ (winner's spending) $-\ln ($ loser's spending) in pre-redistricting election; i.e., freshmen were not yet incumbents in the prior election.

8 Because House candidates are not required to report to the FEC expenditures under $\$ 5,000$, we replicate Canes-Wrone, Brady, and Cogan $(2002,131)$ and Jacobson $(1990,338)$ in assigning $\$ 5,000$ in current spending to these candidates. This amount is then converted into 1990 constant dollars for all years.

${ }^{9}$ Two other studies operationalizing campaign expenditures in a similar form are Canes-Wrone, Brady, and Cogan $(2002,131)$ and Carson, Koger, Lebo, and Young $(2010,607)$.

10

We do not include as commission states those stipulating that commissions are to be used only in case of state legislative deadlock. Our list of commission states thus consists of Iowa, Hawaii, New Jersey, and Washington in all three redistricting cycles, Arizona and Idaho in the second and third cycles, and California in the third cycle. (While technically not having a commission system, Iowa qualifies for inclusion by virtue of assigning redistricting responsibility to non-partisan legislative staff, who then put their plan before state legislators for a straight yes or no vote.)

11

Desposato and Petrocik (2003, 19-21), Hood and McKee (2013, 206-16), McKee (2008a, 126-27), and McKee (2013, 634-39) have found that the detrimental effects of gaining new constituents in years featuring a partisan tide are mitigated for the advantaged party, presumably because transplanted voters are swept along by the tide despite their unfamiliarity with the new incumbent. Our own results comport with theirs in the two elections we analyze that featured such a tide; i.e., Republicans are hurt significantly less than Democrats in 2002, while the reverse is true in 2012.

12 Path analysis is a form of Structural Equation Modeling (SEM), in which all variables are directly measured (i.e., "manifest" variables). (The more general case of SEM involves manifest as well as "latent" variables, which are measured in terms of more than one observed indicator.) Path analysis is appropriate in analyses where there are multiple dependent variables that are causally related to one another, in addition to being influenced by a series of exogenous independent variables. Aside from generation of one parameter for each right hand side variable employed in the structural equations, parameters are also generated for the variance estimates of the exogenous variables, the error variance estimates of the endogenous variables, and the covariance estimates of each pair of exogenous variables.

13 Marginal districts are defined as those won in the pre-redistricting election by 60 percent or less of the two-party House vote.

14 The commission-based plans considered in the previous section are included within this Bipartisan/Court Ordered category. 
15 In the more constrained circumstances of southern Republican challengers in 1992, however, McKee finds that their spending was greater when more new constituents were added to the Democratic House incumbent's district $(2010,123)$.

16

On pages 5-6, the case was made for analyzing the effects of redistricting on a dependent variable operationalized in terms of inter-election change in incumbent election margins. Alternatively, we also undertook the regression analysis in Table 1 and the path analysis in Figures 1-3 by the statistically equivalent procedure of regressing incumbents' post-redistricting margins on the independent variables in the equations, plus a lagged variable for incumbents' pre-redistricting margins. All significant variables in the original analyses retained significance in the revised calculations, and there were no newly significant variables. The three measures of overall fit for the path analyses, however, all became at least somewhat weaker, especially the Root Mean Square Error of Approximation, which more than doubled in size from . 054 to .111

17 In sorting out the individual importance of these two paths, the compound paths in 2002 going through both partisan change and intactness - - i.e., where the former is a cause of the latter - - must of necessity be excluded from the calculations.

18 districts.

8 Districts requiring no adjustments in population size are combined together with under-populated

19 The 1988 presidential vote of respondents in the 1990-1991-1992 Full Panel File had to be ascertained by means of their recall of this vote when they were interviewed in 1990 .

20

The only other study we are aware of that deals systematically with the consequences for an incumbent of losing constituents is Yoshinaka and Murphy. They deal with a "fragmentation" variable that integrates information on the number of constituents removed from a district with information on the number of districts to which these constituents are dispersed $(2009,453)$. Fragmentation is a weapon sometimes employed by partisan line drawers to undermine incumbents of the out-party by parceling out most of their constituents to several surrounding districts, thus making it difficult to find a place to run. Despite their relationship to one another, however, fragmentation and our own constituent removal variable get at different underlying phenomena. The former will very likely dampen an incumbent's reelection prospects, whereas constituent removal, as we have just found, may lead to greater safety if the displaced constituents, irrespective of where they end up, are mainly of the non-incumbent party.

21

These calculations take into account both the direct effect that intactness or change in partisanship has on reelection margin, as well as the indirect effect on margin channeled through the incumbent-challenger spending difference. For example, the unstandardized path coefficients in 2002 for the partisan change-reelection margin, partisan change-spending difference, and spending difference-reelection relationships are $.881,15.858$, and .012 , respectively. Therefore, compared to having a district with no partisan change, a member with the average amount of change (.006) would be expected to experience the following increase in reelection margin: [.881x.006] $[[15.858 x .006] x .012]=.006$ (i.e., .6 percent). 


\section{Bibliography}

Abramowitz, Alan I. 2010. The Disappearing Center: Engaged Citizens, Polarization, and American Democracy. New Haven: Yale University Press.

Allison, Paul D. 1990. "Change Scores as Dependent Variables in Regression Analysis." Sociological Methodology 20: 93-114.

Ansolabehere, Stephen, James M. Snyder, Jr., and Charles Stewart, III. 2000. "Old Voters, New Voters, and the Personal Vote: Using Redistricting to Measure the Incumbency Advantage." American Journal of Political Science 44 (January): 17-34.

Boatright, Robert G. 2004. "Static Ambition in a Changing World: Legislators' Preparations for, and Responses to, Redistricting." State Politics and Policy Quarterly 4 (Winter): 436-54.

Bollen, Kenneth A. 1989. Structural Equations with Latent Variables. New York: John Wiley and Sons.

Bullock III, Charles S. 2010. Redistricting: The Most Political Activity in America. Lanham, MD.: Rowman and Littlefield.

Canes-Wrone, Brandice, David W. Brady, and John F. Cogan. 2002. "Out of Step, Out of Office: Electoral Accountability and House Members' Voting." American Political Science Review 96 (March): 127-40.

Carson, Jamie L., Gregory Koger, Matthew J. Lebo, and Everett Young. 2010. "The Electoral Costs of Party Loyalty in Congress." American Journal of Political Science 54 (July): 598-616.

Crespin, Michael H. 2005. "Using Geographic Information Systems to Measure District Change, 2000-2002." Political Analysis 13 (No. 3): 253-60.

Desposato, Scott W., and John R. Petrocik. 2003. "The Variable Incumbency Advantage: New Voters, Redistricting, and the Personal Vote." American Journal of Political Science 47 (January): 18-32.

- 2005. "Redistricting and Incumbency: The New Voter Effect." In Redistricting in the New Millennium, ed. Peter F. Galderisi. Lanham, MD.: Lexington Books.

Forgette, Richard, and Glenn Platt. 2005. "Redistricting Principles and Incumbency Protection in the U.S. Congress." Political Geography 24 (November): 934-51.

Friedman, John N., and Richard T. Holden. 2009. "The Rising Incumbent Reelection Rate: What's Gerrymandering Got to Do with It?" Journal of Politics 71 (April): 593-611.

Hayes, Danny, and Seth C. McKee. 2009. "The Participatory Effects of Redistricting." American Journal of Political Science 53 (October): 1006-23.

Hood III, M. V., and Seth C. McKee. 2010. "Stranger Danger: Redistricting, Incumbent Recognition, and Vote Choice." Social Science Quarterly 91 (June): 344-58. . 2013. "Unwelcome Constituents: Redistricting and Countervailing Partisan Tides." State Politics and Policy Quarterly 13 (June): 203-24.

$\mathrm{Hu}$, Li-tze, and Peter M. Bentler. 1999. "Cutoff Criteria for Fit Indexes in Covariance Structure Analysis: Conventional Criteria versus New Alternatives.” Structural Equation Modeling: A Multidisciplinary Journal 6 (No. 1): 1-55. 
Jacobson, Gary C. 1990. "The Effects of Campaign Spending in House Elections: New Evidence for Old Arguments.” American Journal of Political Science 34 (May): 334-362.

- 2011. A Divider, Not a Uniter: George W. Bush and the American People, $2^{\text {nd }}$ ed., New York: Pearson.

Liker, Jeffrey K., Sue Augustyniak, and Greg J. Duncan. 1985. "Panel Data and Models of Change: A Comparison of First Difference and Conventional Two-Wave Models." Social Science Research 14 (March): 80-101.

Loehlin, John C. 2004. Latent Variable Models: An Introduction to Factor, Path, and Structural Equation Analysis. Mahwah, NJ: Lawrence Erlbaum Associates.

McDonald, Michael P. 2004. "A Comparative Analysis of Redistricting Institutions in the United States, 2001-02.” State Politics and Policy Quarterly 4 (Winter): 371-95.

McKee, Seth C. 2008a. "The Effects of Redistricting on Voting Behavior in Incumbent U.S. House Elections, 1992-1994.” Political Research Quarterly 61 (March): 122-33.

- 2008b. "Redistricting and Familiarity with U.S. House Candidates." American Politics Research 36 (November): 962-79.

- 2010. Republican Ascendancy in Southern U.S. House Elections. Boulder, CO: Westview.

- 2013. "Political Conditions and the Electoral Effects of Redistricting." American Politics Research 41 (July): 623-46.

Rush, Mark E. 2000. Does Redistricting Make a Difference?: Partisan Representation and Electoral Behavior. Lanham, MD: Lexington Books.

Yoshinaka, Antoine, and Chad Murphy. 2009. "Partisan Gerrymandering and Population Instability: Completing the Redistricting Puzzle." Political Geography 28 (November): 451-62. . 2011. "The Paradox of Redistricting: How Partisan Mapmakers Foster Competition but Disrupt Representation." Political Research Quarterly 64 (June): 435-47. 